Reprod. Nutr. Dévelop., 1983, 23 (5), 915-926.

\title{
Somatic development in premature mice from birth to weaning
}

\author{
Jacqueline LOCTIN, P. DELOST
}

Laboratoire de Physiologie animale, Université de Clermont-Ferrand et ERA CNRS 414, Endocrinologie du Développement, 24, avenue des Landais, B.P. 45, 63170 Aubière, France.

\begin{abstract}
Summary. This paper reports a statistical and transversal study of growth in about 2400 surviving premature mice during neonatal development. The mice were removed by caesarean section on day 19 of pregnancy and reanimated for $30 \mathrm{~min}$; surviving mice as well as newborns delivered vaginally on day 20 (control mice) were raised from birth to day 20 by nursing mothers spontaneously delivered at the same time. Only litters from nursing dams which suckled newborns regularly were used in the statistical study. Somatic development in the premature mice and newborn controls was estimated by changes in body weight and in the weight of several organs (liver, kidney, adrenal glands) after the newborns had been killed at five developmental stages : 30 min after reanimation or parturition, $6 \mathrm{~h}$ after birth and at $9 \mathrm{~h}$ on days 2, 6 and 20 . Growth was analysed by growth curves, percentage of weight gain per day, regression lines and allometric lines; weight gain was calculated as a function of the number of newborns per litter. The low birth weight of live premature mice affected body weight and kidney and adrenal weights. After an early, transitory loss of body and organ weights, which occurred during the first neonatal day, the weight handicaps of premature mice were overcome before neonatal day 20 as follows : adrenal weight between $6 \mathrm{~h}$ and day 2, liver weight between days 2 and 6, kidney and body weights between days 6 and 20 . Throughout these stages, the weight gain of body and organs was higher than that of full-term newborns. The weight gains of premature mice, like those of full-term newborns, were in inverse ratio to the number of newborns per litter. The role of some factors involved in the growth of organs of premature mice has been discussed and the somatic development of surviving premature mice has been compared to that of smallest premature human infants.
\end{abstract}

\section{Introduction.}

As the mortality of prematures has been studied carefully in primates, domestic animals and rodents (Loctin and Delost, 1983a), there is an increasing awareness of the need to assess the growth of surviving premature newborns of these species. Since the birth weight of live premature newborns is lower than that of full-term newborns, the question is whether premature newborns still continue to show differences and handicaps after the neonatal period. Only a few investigations have been carried out on the postnatal growth of premature newborns in species other than man. 
Over the past 30 years many studies of the later growth' and development of premature infants appearing in the literature have reported widely varying conclusions (Loctin, 1980). Many factors besides somatic development are involved in the conflicting results on postnatal growth of premature infants. Indeed, the chief difficulty in planning a long-term study of this type is to know the environmental factors. These can be controlled in animals, but there are no statistical studies on the postnatal growth of premature animals. It is only known that the weight gain of premature piglet per day from birth to weaning is higher than that of full-term piglet (Aumaitre et al., 1979).

In spite of the mortality occurring during reanimation and postnatal breeding, previous experiments have shown that many premature mice obtained by caesarean section on day 19 of pregnancy survive (Loctin, 1980 ; Loctin and Delost, 1983a). We thought it would be interesting to compare the postnatal growth of premature mice with that of full-term newborn mice and also existing data on the growth of premature infants with those of a rodent model. The aim of the present paper was to do a statistical study of body and organ growth from birth to weaning in live premature mice obtained by caesarean section. We could not carry out a longitudinal development study of body weight in premature mice because it was feared that the dams would reject the live newborns if they were weighed during development. Therefore, we did a transversal study by killing newborns at several stages of postnatal development. This method also permitted us to weigh the organs; the liver, kidney and adrenals were chosen because they are involved in the survival of premature mice (Loctin and Delost, 1983a).

\section{Material and methods.}

Animals. - The newborns were issued from primiparous female mice (Swiss $C D_{1}$ strain) of the same age ( 3 months). Pregnant mice, obtained under conditions described in a previous work (Loctin and Delost, 1983a), were isolated from day 1 of pregnancy in indididual cages under controlled conditions of temperature $\left(25 \pm 2{ }^{\circ} \mathrm{C}\right)$, nutrition and natural lighting. Full-term newborns (control animals) were delivered spontaneously and vaginally on day 20 of pregnancy. Premature mice were obtained by caesarean section between 9 and $12 \mathrm{~h}$ on day 19 of pregnancy immediately after the dam was decapitated ; they were reanimated for $30 \mathrm{~min}$ in a warming box $\left(38^{\circ} \mathrm{C}\right)$ soaked with physiological serum and provided with an oxygen tent (Loctin, 1980). After respiration and reanimation, these live mice, as well as newborns delivered vaginally on day 20 and taken from their own dams less than $1 \mathrm{~h}$ after parturition, were raised from birth to day 20 (weaning) by nursing mothers spontaneously delivered at the same time. Only litters from nursing dams which suckled newborns immediately after birth and regularly during neonatal development were used in the statistical study of somatic growth, and only the strong live newborns within these litters were killed and weighed. Several groups of premature mice and full-term mice were killed (1) at birth (30 min after reanimation or parturition), (2) $6 \mathrm{~h}$ after birth 
and (3) at $9 \mathrm{~h}$ on neonatal days 2, 6 and 20. To study growth at birth and during neonatal developmental only litters with 6-13 newborns were used; the litters were pooled then divided into 4 groups each containing 6-7, 8-9, 10-11 and 12-13 newborns. In spite of breeding mortality (Loctin and Delost, 1983a), the study was carried out using 259 litters and 2463 newborn mice.

Statistical study of somatic development. - The somatic postnatal development of premature and full-term mice was compared by analysing changes in body weight and the weight of several organs (liver, kidney, adrenal glands). At each of the five studied stages of postnatal development, the newborns were individually weighed before they were killed. The animals were bled by decapitation; the liver, left kidney and two adrenal glands were immediately weighed and frozen at $-35^{\circ} \mathrm{C}$ for other investigations. In each litter, these organs were pooled by sex before weighing ( 2 weighings per litter). Since no significant sex differences were observed in any of the parameters measured, the data on male and female offsprings were combined. Somatic development was estimated (1) by growth curves from birth to day 20 ; (2) by weight gain or loss $(\mathrm{mg} /$ day) at 4 stages : birth to day 2 , days 2 to 6 , days 6 to 20 and birth to day $20 ;(3)$ by the percentage of weight gained or lost at 5 stages : birth to $6 \mathrm{~h}, 6 \mathrm{~h}$ to day 2 , days 2 to 6 , days 6 to 20 and birth to day 20 . These calculations were carried out on the total of the litters and as a function of the number of newborns per litter.

Correlations of body weight and the weight of liver, kidney and adrenals with age were estimated by regression with the correlation coefficient $r$ and the security coefficient $t$ for probability higher than $95 \%$. The regression lines of premature mice and full-term newborns were compared using analysis of variance and Fisher's F-test. Allometric lines and allometric coefficients for liver, kidney and adrenal weights in relation with body weight were evaluated by the mathematical model, log. organ weight/log. body weight, from Cantier et al. (1969). These calculations were only carried out on the total of the litters.

The means \pm SEM are given; Student's t-test was used to calculate probability and significance.

\section{Results.}

\section{Birth weight.}

Mean body weight and mean kidney and adrenal weights were lower in premature mice removed on day 19 of pregnancy and killed $30 \mathrm{~min}$ after reanimation than in newborns delivered vaginally at term on day 20 (table 1 ). Statistical analysis using weight as a function of the number of newborns per litter showed that body, kidney and adrenal weights increased in surviving premature mice and in full-term newborns when the number of newborns per litter decreased, and that the difference in weight $(\%)$ between premature mice and full-term newborns was equal, whatever the number of newborns per litter. 
Only mean liver weight, similar in birth in both premature mice and full-term newborns, varied as a function of the number of newborns per litter.

\section{TABLE 1}

Differences in weights ( $\mathrm{mg}$ ) of body, liver, kidney and adrenals between full-term newborns and premature mice at birth, $6 \mathrm{~h}$ after birth and at $9 \mathrm{~h}$ on neonatal days 2, 6 and 20 . The full-term mice were delivered spontaneously and vaginally on day 20 of pregnancy (control animals) and the prematures were removed by caesarean section on day 19 of pregnancy. Both groups were raised by nursing dams from $30 \mathrm{~min}$ after birth or reanimation. Values are means \pm SEM. The numbers in parentheses are the number of mice weighed or the number of weighings.

\begin{tabular}{|c|c|c|c|c|c|c|c|}
\hline Parameter & $\begin{array}{l}\text { Stage } \\
\text { after } \\
\text { birth }\end{array}$ & Control anim & & Premature $\mathrm{m}$ & & & $\begin{array}{l}\text { Change in } \% \\
\text { of control value } \\
\text { and } \mathrm{P}\end{array}$ \\
\hline $\begin{array}{l}\text { Bbdy } \\
\text { weight }\end{array}$ & $\begin{array}{l}\text { Birth } \\
6 \mathrm{~h} \\
\text { day } 2 \\
\text { day } 6 \\
\text { day } 20\end{array}$ & $\begin{array}{l}1540 \pm 6 \\
1620 \pm 8 \\
1810 \pm 10 \\
3210 \pm 40 \\
7740 \pm 110\end{array}$ & $\begin{array}{l}(247) \\
(218) \\
(352) \\
(185) \\
(185)\end{array}$ & $\begin{array}{l}1230 \pm 6 \\
1210 \pm 5 \\
1460 \pm 9 \\
2870 \pm 30 \\
7970 \pm 110\end{array}$ & $\begin{array}{l}(297) \\
(284) \\
(328) \\
(162) \\
(195)\end{array}$ & $\begin{array}{r}20 \\
25 \\
19 \\
10 \\
3\end{array}$ & $\begin{array}{l}\mathrm{P}<0.001 \\
\mathrm{P}<0.001 \\
\mathrm{P}<0.001 \\
\mathrm{P}<0.001 \\
\text { NS }\end{array}$ \\
\hline $\begin{array}{l}\text { Liver } \\
\text { weight }\end{array}$ & $\begin{array}{l}\text { Birth } \\
6 \mathrm{~h} \\
\text { day } 2 \\
\text { day } 6 \\
\text { day } 20\end{array}$ & $\begin{array}{r}84.5 \pm 1.3 \\
86.2 \pm 1.0 \\
74.0 \pm 1.0 \\
106.2 \pm 2.9 \\
313.8 \pm 13.8\end{array}$ & $\begin{array}{l}(46) \\
(43) \\
(65) \\
(41) \\
(40)\end{array}$ & $\begin{array}{r}86.3 \pm 1.2 \\
74.2 \pm 0.9 \\
65.2 \pm 1.0 \\
101.1 \pm 2.4 \\
326.2 \pm 12.7\end{array}$ & $\begin{array}{l}(70) \\
(54) \\
(60) \\
(34) \\
(42)\end{array}$ & $\begin{array}{r}2 \\
14 \\
12 \\
5 \\
4\end{array}$ & $\begin{aligned} & \text { NS } \\
P & <0.001 \\
P & <0.001 \\
& N S \\
& N S\end{aligned}$ \\
\hline $\begin{array}{l}\text { Kidney } \\
\text { weight }\end{array}$ & $\begin{array}{l}\text { Birth } \\
6 \mathrm{~h} \\
\text { day } 2 \\
\text { day } 6 \\
\text { day } 20\end{array}$ & $\begin{aligned} 6.8 \pm & 0.1 \\
7.2 \pm & 0.1 \\
8.5 \pm & 0.10 \\
17.8 \pm & 0.50 \\
52.1 \pm & 1.60\end{aligned}$ & $\begin{array}{l}(48) \\
(44) \\
(65) \\
(41) \\
(40)\end{array}$ & $\begin{aligned} 4.9 \pm & 0.100 \\
4.9 \pm & 0.05 \\
6.5 \pm & 0.1 \\
15.8 \pm & 0.4 \\
52.7 \pm & \pm .6\end{aligned}$ & $\begin{array}{l}(71) \\
(56) \\
(62) \\
(34) \\
(42)\end{array}$ & $\begin{array}{r}28 \\
31 \\
23 \\
11 \\
1\end{array}$ & $\begin{aligned} \mathrm{P} & <0.001 \\
\mathrm{P} & <0.001 \\
\mathrm{P} & <0.001 \\
0.001 & <\mathrm{P}<0.01 \\
\text { NS } & \end{aligned}$ \\
\hline $\begin{array}{l}\text { Adrenal } \\
\text { weight }\end{array}$ & $\begin{array}{l}\text { Birth } \\
6 \mathrm{~h} \\
\text { day } 2 \\
\text { day } 6 \\
\text { day } 20\end{array}$ & 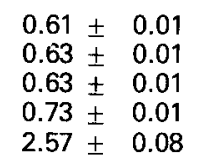 & $\begin{array}{l}(48) \\
(44) \\
(65) \\
(41) \\
(40)\end{array}$ & $\begin{array}{ll}0.53 \pm & 0.006 \\
0.56 \pm & 0.007 \\
0.64 \pm & 0.01 \\
0.74 \pm & 0.01 \\
2.49 \pm & 0.06\end{array}$ & $\begin{array}{l}(72) \\
(56) \\
(62) \\
(34) \\
(42)\end{array}$ & $\begin{array}{r}13 \\
11 \\
1 \\
1 \\
3\end{array}$ & $\begin{array}{c}P<0.001 \\
P<0.001 \\
\text { NS } \\
\text { NS } \\
\quad N S\end{array}$ \\
\hline
\end{tabular}

\section{Postnatal somatic development.}

a) Body growth (fig. 1). - In full-term newborns body growth started between birth and $6 h$, then increased regularly until day 20. In premature mice, body weight decreased between birth and $6 \mathrm{~h}$, then increased from $6 \mathrm{~h}$ to day 20. The mean body weight of premature mice caught up with that of full-term newborns between days 6 and 20 since there was no significant difference between the two groups at day 20 . The percentage of mean body weight gain was higher in premature mice at all stages of development from $6 \mathrm{~h}(548 \%)$ form birth to day 20) than in full-term newborns (402 \%) (table 2). However, in comparison with control animals, mean body weight gain $(\mathrm{mg} /$ day) of premature mice was lower between birth and day 2, equal between days 2 and 6 and higher 
between days 6 and 20, so that from birth to day 20, it was higher in premature mice (350 mg/day) than in full-term newborns $(320 \mathrm{mg} /$ day) (table 3 ). In premature mice, as well as in full-term newborns, mean body weight gain (percentage and $\mathrm{mg} /$ day) increased when the number of newborns per litter decreased (tables 2,3). There was no difference in the regression lines of mean body weight between full-term newborns and prematures from birth to day 20 , but from days 2 to 20 the regression lines of mean body weight of premature mice and full-term newborns were significantly different $(P=95 \%)$. This confirmed that body growth was higher form day 6 after birth in premature mice than in full-term newborns.

\section{b) Organ growth.}

- Kidney weight (fig. 1). The mean kidney weight of full-term newborns increased regularly from birth to day 20 according to the regression line. The mean kidney weight of premature mice did not vary between birth and $6 \mathrm{~h}$, then

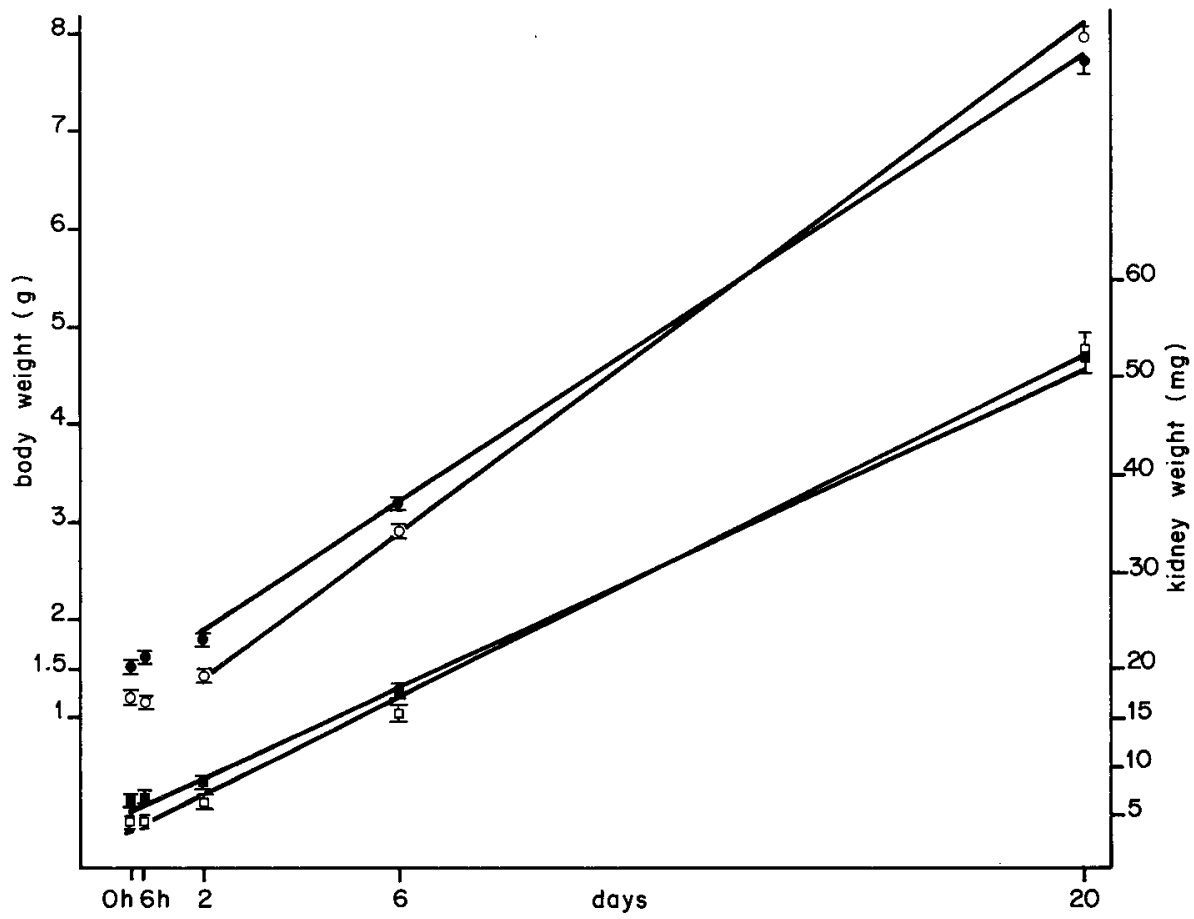

FIG. 1. - Changes in mean body weight and mean kidney weight of premature mice from birth to neonatal day 20 (body: 0 ; kidney : $\square$ ). The mice were removed by caesarean section on day 19 of pregnancy and the full-term newborn mice (body: 0 ; kidney : $\square$ ) were delivered spontaneously and vaginally on day 20 of pregnancy. Values are means \pm SEM. The regression lines were established from days 2 to 20 for body weight and from birth to day 20 for kidney weight.

$: y=1.19+0.33 x ; r=0.999 ; t=69 . \quad O: y=0.72+0.36 x ; r=0.999 ; t=170$.

$\square: y=5.46+2.30 x ; r=0.997 ; t=23.5 . \quad \square: y=3.20+2.44 x ; r=0.997 ; t=21.2$ 
increased from $6 \mathrm{~h}$ to day 20. The regression line from birth to day 20 did not differ from that of full-term newborns; these lines were also similar between days 2 to 20. The mean kidney weight of premature mice caught up with that of full-term newborns between days 6 and 20 ; at day 20 it was equal in the two groups. The mean percentage of kidney weight gain of premature mice was higher than that of full-term newborns at all stages from stage $6 \mathrm{~h}$-day 2 ; it was $975 \%$ from birth to day 20 and $669 \%$ in control animals (table 2). The mean kidney weight gain (mg/day) of premature mice was higher only through days 6 to 20 (table 3 ). Kidney weight gain was in inverse ratio to the number of newborns per litter from days 6 to 20 and from birth to day 20 in both groups. Changes in kidney weight in relation with body weight from birth to day 20 showed positive and similar allometry (1.26) in premature mice and full-term newborns.

TABLE 2

Differences in the percentages of weight gain or loss 1 - 1 of body, kidney and adrenals between fullterm newborn mice and premature mice from birth to day 20 after birth. The full-term mice were delivered spontaneously and vaginally on day 20 of pregnancy (control animals, $C$ ) and the premature mice (P) were removed by caesarean section on day 19 of pregnancy. Both groups were raised by nursing dams from $30 \mathrm{~min}$ after birth or reanimation.

\begin{tabular}{|c|c|c|c|c|c|c|c|c|c|c|c|}
\hline \multirow{3}{*}{ Parameter } & \multirow{3}{*}{$\begin{array}{c}\text { Number of } \\
\text { newborns } \\
\text { per litter }\end{array}$} & \multicolumn{10}{|c|}{ Stage after birth } \\
\hline & & \multicolumn{2}{|c|}{ Birth-6 h } & \multicolumn{2}{|c|}{6 h-day 2} & \multicolumn{2}{|c|}{ day 2-day 6} & \multicolumn{2}{|c|}{ day 6-day 20} & \multicolumn{2}{|c|}{ Birth-day 20} \\
\hline & & c & $\mathrm{P}$ & C & $P$ & $C$ & $P$ & $\mathrm{C}$ & $\mathbf{P}$ & C & $P$ \\
\hline \multirow[t]{2}{*}{$\begin{array}{l}\text { Body } \\
\text { weight }\end{array}$} & $\begin{array}{c}12-13 \\
10-11 \\
8-9 \\
6-7\end{array}$ & $\begin{array}{l}4 \\
6 \\
8 \\
6\end{array}$ & $\begin{array}{r}0 \\
-\quad 3 \\
-\quad 6 \\
-\quad 7\end{array}$ & $\begin{array}{l}12 \\
13 \\
14 \\
16\end{array}$ & $\begin{array}{l}15 \\
23 \\
27 \\
25\end{array}$ & $\begin{array}{l}70 \\
68 \\
68 \\
88\end{array}$ & $\begin{array}{r}94 \\
99 \\
82 \\
110\end{array}$ & $\begin{array}{l}126 \\
130 \\
160 \\
165\end{array}$ & $\begin{array}{l}145 \\
163 \\
201 \\
207\end{array}$ & $\begin{array}{l}350 \\
365 \\
438 \\
512\end{array}$ & $\begin{array}{l}449 \\
526 \\
556 \\
652\end{array}$ \\
\hline & $\begin{array}{c}\text { Total of } \\
\text { litters }\end{array}$ & 5 & -2 & $\cdot 12$ & 21 & 77 & 96 & 141 & 178 & 402 & 548 \\
\hline \multirow[t]{2}{*}{$\begin{array}{l}\text { Liver } \\
\text { weight }\end{array}$} & $\begin{array}{c}12-13 \\
10-11 \\
8-9 \\
6-7\end{array}$ & $\begin{array}{r}1 \\
8 \\
-\quad 1 \\
1\end{array}$ & $\begin{array}{l}-9 \\
-13 \\
-18 \\
-24\end{array}$ & $\begin{array}{l}-15 \\
-13 \\
-\quad 15 \\
-\quad 4\end{array}$ & $\begin{array}{r}-19 \\
-\quad 12 \\
-\quad 8 \\
1\end{array}$ & $\begin{array}{l}30 \\
30 \\
45 \\
49\end{array}$ & $\begin{array}{l}55 \\
49 \\
42 \\
58\end{array}$ & $\begin{array}{l}187 \\
165 \\
182 \\
253\end{array}$ & $\begin{array}{l}153 \\
216 \\
253 \\
255\end{array}$ & $\begin{array}{l}221 \\
223 \\
244 \\
412\end{array}$ & $\begin{array}{l}186 \\
262 \\
280 \\
328\end{array}$ \\
\hline & $\begin{array}{l}\text { Total of } \\
\text { litters }\end{array}$ & 2 & -14 & -14 & -12 & 43 & 55 & 195 & 223 & 271 & 278 \\
\hline \multirow[t]{2}{*}{$\begin{array}{l}\text { Kidney } \\
\text { weight }\end{array}$} & $\begin{array}{c}12-13 \\
10-11 \\
8-9 \\
6-7\end{array}$ & $\begin{array}{r}5 \\
10 \\
8 \\
3\end{array}$ & $\begin{array}{r}2 \\
-\quad 3 \\
-\quad 2\end{array}$ & $\begin{array}{l}19 \\
15 \\
24 \\
20\end{array}$ & $\begin{array}{l}23 \\
41 \\
35 \\
38\end{array}$ & $\begin{array}{r}96 \\
109 \\
87 \\
128\end{array}$ & $\begin{array}{l}145 \\
133 \\
124 \\
147\end{array}$ & $\begin{array}{l}178 \\
166 \\
212 \\
210\end{array}$ & $\begin{array}{l}192 \\
221 \\
262 \\
256\end{array}$ & $\begin{array}{l}579 \\
608 \\
689 \\
779\end{array}$ & $\begin{array}{r}799 \\
926 \\
1,041 \\
1,083\end{array}$ \\
\hline & $\begin{array}{l}\text { Total of } \\
\text { litters }\end{array}$ & 6 & 1 & 18 & 33 & 110 & 141 & 193 & 235 & 669 & 975 \\
\hline \multirow[t]{2}{*}{$\begin{array}{l}\text { Adrenal } \\
\text { weight }\end{array}$} & $\begin{array}{c}12-13 \\
10-11 \\
8-9 \\
6-7\end{array}$ & $\begin{array}{r}3 \\
14 \\
3 \\
-\quad 3\end{array}$ & $\begin{array}{l}8 \\
4 \\
6 \\
3\end{array}$ & $\begin{array}{r}-2 \\
-\quad 9 \\
1 \\
20\end{array}$ & $\begin{array}{r}7 \\
18 \\
9 \\
32\end{array}$ & $\begin{array}{l}17 \\
17 \\
14 \\
12\end{array}$ & $\begin{array}{r}22 \\
23 \\
13 \\
3\end{array}$ & $\begin{array}{l}214 \\
248 \\
278 \\
266\end{array}$ & $\begin{array}{l}205 \\
216 \\
259 \\
265\end{array}$ & $\begin{array}{l}274 \\
323 \\
312 \\
359\end{array}$ & $\begin{array}{l}329 \\
377 \\
368 \\
374\end{array}$ \\
\hline & $\begin{array}{l}\text { Total of } \\
\text { litters }\end{array}$ & 3 & 6 & 0 & 14 & 16 & 16 & 252 & 236 & 321 & 370 \\
\hline
\end{tabular}


TABLE 3

Differences in weight gain or loss (-) (mg/day) of body, liver, kidney and adrenals between fullterm newborn mice and premature mice from birth to day 20 after birth. The full-term mice were delivered spontaneously and vaginally on day 20 of pregnancy (control animals, C) and the premature mice $(P)$ were removed by caesarean section on day 19 of pregnancy. Both groups were raised by nursing dams from 30 min after birth or reanimation.

\begin{tabular}{|c|c|c|c|c|c|c|c|c|c|}
\hline \multirow{3}{*}{ Parameter } & \multirow{3}{*}{$\begin{array}{l}\text { Number of } \\
\text { newborns } \\
\text { per litter }\end{array}$} & \multicolumn{8}{|c|}{ Stage after birth } \\
\hline & & \multicolumn{2}{|c|}{ Birth-day 2} & \multicolumn{2}{|c|}{ day 2-day 6} & \multicolumn{2}{|c|}{ day 6-day 20} & \multicolumn{2}{|c|}{ Birth-day 20} \\
\hline & & $\mathrm{C}$ & $P$ & $\mathrm{C}$ & $\mathbf{P}$ & C & $\mathbf{P}$ & C & $P$ \\
\hline \multirow[t]{2}{*}{$\begin{array}{l}\text { Body } \\
\text { weight }\end{array}$} & \multirow{2}{*}{$\begin{array}{c}12-13 \\
10-11 \\
8-9 \\
6-7 \\
\text { Total of } \\
\text { litters }\end{array}$} & $\begin{array}{l}250 \\
310 \\
360 \\
380\end{array}$ & $\begin{array}{l}180 \\
240 \\
250 \\
220\end{array}$ & $\begin{array}{l}300 \\
310 \\
320 \\
440\end{array}$ & $\begin{array}{l}320 \\
370 \\
320 \\
420\end{array}$ & $\begin{array}{l}260 \\
280 \\
360 \\
440\end{array}$ & $\begin{array}{l}270 \\
340 \\
400 \\
490\end{array}$ & $\begin{array}{l}270 \\
290 \\
350 \\
440\end{array}$ & $\begin{array}{l}270 \\
340 \\
380 \\
460\end{array}$ \\
\hline & & 270 & 230 & 350 & 350 & 320 & 360 & 320 & 350 \\
\hline \multirow[t]{2}{*}{$\begin{array}{l}\text { Liver } \\
\text { weight }\end{array}$} & \multirow{2}{*}{$\begin{array}{c}12-13 \\
10-11 \\
8-9 \\
6-7 \\
\text { Total of } \\
\text { litters }\end{array}$} & $\begin{array}{r}-11.3 \\
-\quad 5.0 \\
-\quad 14.3 \\
-\quad 2.5\end{array}$ & $\begin{array}{l}-22.3 \\
-20.0 \\
-22.0 \\
-22.5\end{array}$ & $\begin{array}{r}5.2 \\
5.7 \\
8.4 \\
10.2\end{array}$ & $\begin{array}{r}8.2 \\
8.2 \\
7.3 \\
10.6\end{array}$ & $\begin{array}{l}12.0 \\
11.7 \\
14.2 \\
22.3\end{array}$ & $\begin{array}{l}10.1 \\
15.3 \\
17.6 \\
21.1\end{array}$ & $\begin{array}{r}9.4 \\
9.5 \\
11.5 \\
18.4\end{array}$ & $\begin{array}{r}8.0 \\
11.9 \\
13.3 \\
16.6\end{array}$ \\
\hline & & -10.5 & -21.0 & 8.0 & 8.9 & 14.8 & 16.1 & 12.1 & 12.6 \\
\hline \multirow[t]{2}{*}{$\begin{array}{l}\text { Kidney } \\
\text { weight }\end{array}$} & \multirow{2}{*}{$\begin{array}{c}12-13 \\
10-11 \\
8-9 \\
6-7 \\
\text { Total of } \\
\text { litters }\end{array}$} & $\begin{array}{l}1.6 \\
1.8 \\
2.4 \\
1.8\end{array}$ & $\begin{array}{l}1.2 \\
1.8 \\
2.0 \\
1.8\end{array}$ & $\begin{array}{l}1.9 \\
2.3 \\
2.0 \\
2.9\end{array}$ & $\begin{array}{l}2.2 \\
2.2 \\
2.1 \\
2.6\end{array}$ & $\begin{array}{l}2.0 \\
2.1 \\
2.6 \\
3.1\end{array}$ & $\begin{array}{l}2.0 \\
2.5 \\
2.8 \\
3.1\end{array}$ & $\begin{array}{l}2.0 \\
2.1 \\
2.3 \\
3.0\end{array}$ & $\begin{array}{l}2.0 \\
2.4 \\
2.6 \\
2.9\end{array}$ \\
\hline & & 1.7 & 1.6 & 2.3 & 2.3 & 2.4 & 2.6 & 2.4 & 2.5 \\
\hline \multirow[t]{2}{*}{$\begin{array}{l}\text { Adrenal } \\
\text { weight }\end{array}$} & \multirow{2}{*}{$\begin{array}{c}12-13 \\
10-11 \\
8-9 \\
6-7 \\
\text { Total of } \\
\text { litters }\end{array}$} & $\begin{array}{l}0.01 \\
0.02 \\
0.03 \\
0.10\end{array}$ & $\begin{array}{l}0.08 \\
0.12 \\
0.08 \\
0.16\end{array}$ & $\begin{array}{l}0.02 \\
0.02 \\
0.01 \\
0.02\end{array}$ & $\begin{array}{l}0.03 \\
0.03 \\
0.02 \\
0.01\end{array}$ & $\begin{array}{l}0.10 \\
0.12 \\
0.14 \\
0.15\end{array}$ & $\begin{array}{l}0.10 \\
0.12 \\
0.12 \\
0.14\end{array}$ & $\begin{array}{l}0.07 \\
0.09 \\
0.10 \\
0.12\end{array}$ & $\begin{array}{l}0.09 \\
0.10 \\
0.10 \\
0.11\end{array}$ \\
\hline & & 0.02 & 0.11 & 0.02 & 0.02 & 0.13 & 0.12 & 0.10 & 0.10 \\
\hline
\end{tabular}

- Adrenal weight (fig. 2). The mean adrenal weight in full-term newborns was unchanged from birth to day 2 and then increased to day 20 , whereas in premature mice it increased from birth (particularly between $6 \mathrm{~h}$ and day 2) and then between days 2 to 20 . The mean adrenal weight of premature mice caught up with that of full-term newborns between $6 \mathrm{~h}$ and day 2 ; at day 2 it was equal in the two groups. According to the regression lines, wich were not statistically different, changes in adrenal weight were similar in the two groups. The mean adrenal weight gain (percentage and $\mathrm{mg} /$ day) was higher in premature mice only from birth to day 2 (tables 2 and 3). There were no evident relationships between adrenal weight gain and the number of newborns per litter in the two groups. Changes in mean adrenal weight in relation with body weight showed negative 


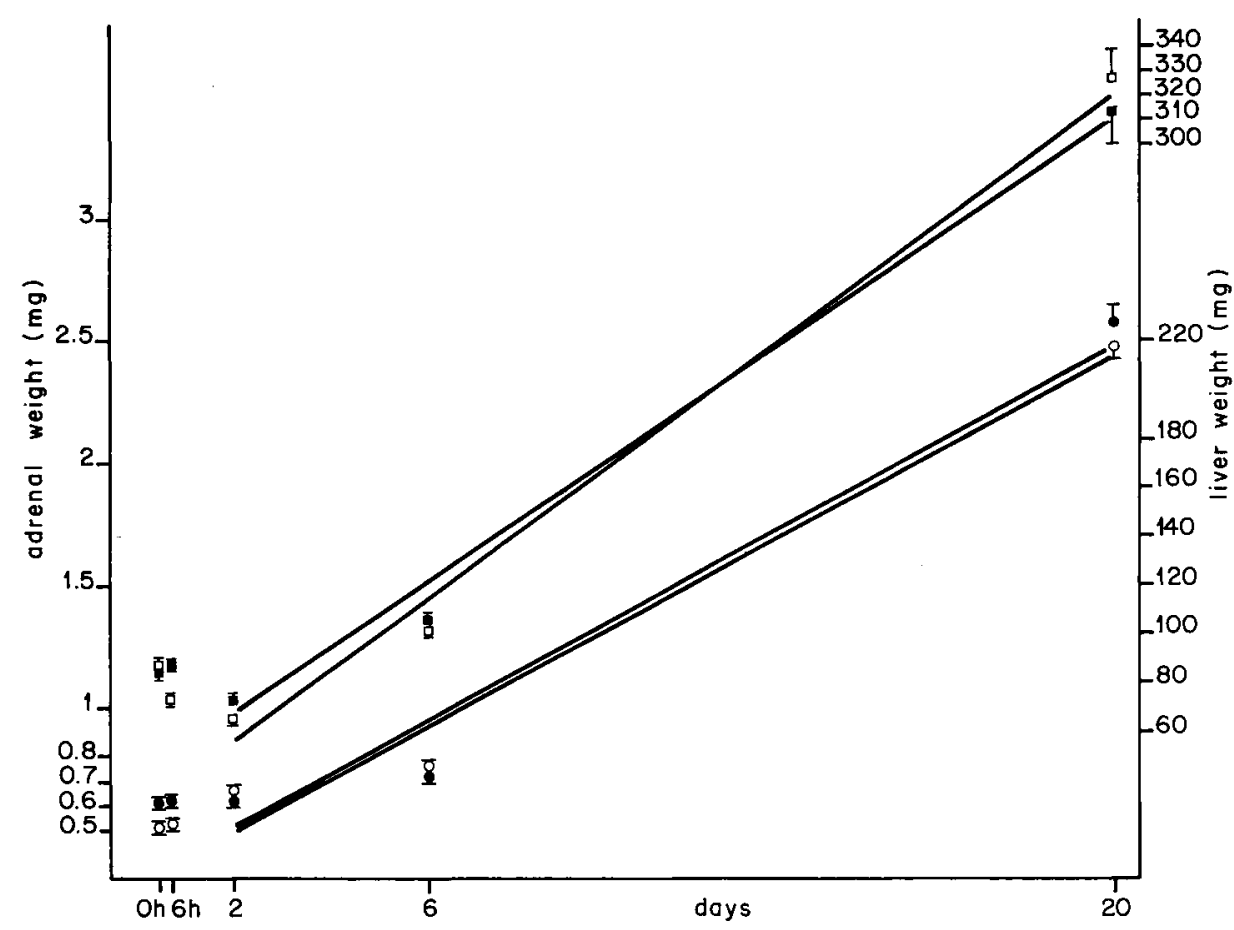

FIG. 2. - Changes in mean adrenal weight and mean liver weight of premature mice ladrenals : 0 ; liver : $\square$ ) from birth to neonatal day 20. The premature mice were removed by caesarean section on day 19 of pregnancy and the full-term newborn mice ladrenals : liver: $\left.{ }^{1}\right)$ were delivered spontaneously and vaginally on day 20 of pregnancy. Values are means \pm SEM. The regression lines were established from days 2 to 20 .

$\square: y=36.5+13.7 x ; r=0.996 ; t=11 . \square: y=24.8+14.9 x ; r=0.996 ; t=12$

$\mathrm{y}=0.25+0.11 \mathrm{x} ; \mathrm{r}=0.986 ; \mathrm{t}=5.9$. $\mathrm{O}: \mathrm{y}=0.28=0.11 \mathrm{x} ; \mathrm{r}=0.996 ; \mathrm{t}=6$

and similar allometry in premature mice $(0.78)$ and full-term newborns (0.84) from birth to day 20 and similar isometry (1) from days 2 to 20 .

- Liver weight (fig. 2). Liver weight was similar at brith in full-term newborns and premature mice. In full-term newborns it was unchanged at $6 \mathrm{~h}$, decreased by $14 \%$ between $6 \mathrm{~h}$ and day 2 and then increased regularly from days 2 to 20 . The mean liver weight of premature mice decreased by $14 \%$ from birth to $6 \mathrm{~h}$ and then by $12 \%$ until day 2 ; at day 2 it was $12 \%$ lower than that of full-term newborns. From days 2 to 20, mean liver weight increased in premature mice, catching up with that of full-term newborns between days 2 and 6 ; at day 6 it did not differ from that of full-term newborns. Between days 2 to 20 , the regression lines of liver weight were not statistically different in premature mice and full-term newborns. The mean liver weight gain (percentage and $\mathrm{mg} /$ day) was higher in premature mice from days 2 to 6 and from days 6 to 20 (tables 2 and 3 ). Liver weight gain was in inverse ratio to the number of newborns per litter in both groups. Changes in mean liver weight in relation with 
body weight showed negative and similar allometry $(0.82)$ in premature mice and full-term newborns from birth to day 20 and similar isometry (1) from days 2 to 20.

\section{Discussion.}

The somatic development of live premature mice was determined by comparing 19-day old surviving premature mice raised from birth to day 20 by nursing dams to full-term newborns also raised by nursing mothers. The two groups could be compared statistically, seeing that in our experiment newborn adoption was homogeneous because we used only litters from nursing mothers that had regularly suckled newborns. The low birth weight of live premature mice affected both body weight and the weight of organs like kidney and adrenal but not liver. The early and transitory weight decrease in premature mice from birth to $6 \mathrm{~h}$ concerned only body weight and liver weight. The decrease in liver weight continued until day 2 ; the liver weight of full-term newborns also decreased between $6 \mathrm{~h}$ and day 2. Several factors were probably involved in this decrease of body weight in premature mice : (1) milk sucking disorders : milk was found in the stomach of $92 \%$ of full-term newborns killed $6 \mathrm{~h}$ after birth and mean milk weight per newborn was $46 \mathrm{mg}$ whereas milk was found in only $50 \%$ of premature mice and mean milk weight per premature was $25 \mathrm{mg}$ (Loctin, 1980) ; (2) there is a high loss of water and sodium in the first 6 neonatal hours in premature mice due to kidney immaturity (Loctin and Delost, 1982). Thus, omitting the weight of stomach milk, the body weight of full-term newborns increased by $2.5 \%$ between birth and $6 \mathrm{~h}$, whereas that of premature mice decreased by $4 \%$. The decrease in newborn liver weight is generally due to liver lipolysis ensuring thermoregulation. The rapid decrease of liver weight $(14 \%)$, occuring only in premature mice between birth and $6 \mathrm{~h}$, was probably related to an increase in liver lipolysis due to thermoregulation disorders since heat production is deficient in the brown fat of premature mice at this stage because of inadequate availability of lipid (Bertin et al., 1982). This high liver lipolysis was the cause of low liver weight in premature mice (14\% less at $6 \mathrm{~h}$ and $12 \%$ less at day 2) compared with full-term newborns.

The present experiments show that, in spite of early and transitory loss of weight, the body and organ weights of premature mice increased considerably throughout postnatal development, so that weight handicaps were overcome before day 20 of life. Thus, body and kidney weights of premature mice caught up with those of full-term newborns between days 6 and 20, liver weight between days 2 and 6 and adrenal weight between $6 \mathrm{~h}$ and day 2 . Indeed, throughout these stages, the weight gain $(\mathrm{mg} / \mathrm{day})$ of the body and organs of premature mice was higher than that of full-term newborns. The regression lines of body weight between days 2 to 20 are significantly different between premature mice and full-term newborns, confirming that body growth is higher in premature mice form day 6 after birth. But, though organ weight gains are higher in premature mice, the regression line for kidney, adrenal 
and liver weights in premature mice does not differ from that of fullterm newborns, and changes in organ weight in relation with body weight show similar allometry or isometry in premature mice and full-term newborns. This phenomenon might indicate that organ growth was similar in both groups from the day the weight handicap was overcome, whereas the body growth of premature mice was always higher. However, this hypothesis could not be confirmed in our experiment because we did not study growth beyond neonatal day 20. Several factors are involved in the precocious recovery of adrenal weight (day 2) in comparison with kidney (day 20) and liver (day 6) weights in premature mice ; (1) the adrenal weight handicap is low at birth (only $13 \%$ ); (2) the adrenal glands are highly stimulated in the first 6 neonatal hours, as shown by an increase in aldosterone (Loctin and Delost, 1982) and corticosterone (Loctin and Delost, $1983 b)$; (3) the kidney weight handicap is very high at birth $(27 \%)$ because the kidneys of premature mice are immature ; (4) after birth the liver weight of premature mice decreases before that of full-term newborns, and at day 2 it is $12 \%$ lower than that of full-term newborns due to higher liver lipolysis.

It is difficult to compare the growth of premature mice with that of other species since the postnatal growth of premature newborns has only been studied statistically in premature human infants. Though environmental factors are not the same during the development of premature mice and the smallest premature infants, it is interesting to study analogies or differences in body growth between premature mice and these infants. The body weight handicap of smallest premature infants at birth is much greater than that of premature mice ; this is probably involved in the fact that infants are slower to overcome this handicap. In premature mice, as in smallest premature there is a decrease in body weight ; this decrease is very short-termed in premature mice lonly during the first 6 neonatal hours) but extends to day 10 in smallest premature (Hatt et al., 1972). From day 2, premature mice rapidly recover the birth body weight of full-term newborns (like kidney and adrenal weights are recovered between $6 \mathrm{~h}$ and day 2), whereas the time until the premature infant reaches his appropriate body weight centile exceeds several weeks (Gairdner and Pearson, 1971 ; Hatt et al., 1972 ; Bourlon, 1973). Another analogy between premature mice and smallest premature infants is that after a transitory decrease, body weight gain is high during postnatal development. In premature infants this fact has been evidenced by plasma STH levels, which are higher than in full-term newborns during the first neonatal weeks (Cornblath et al., 1965). Throughout postnatal development, relationships between the growth rate and birth weight of premature infants are conflicting: the growth rate of the smallest premature infants is either higher (Rossier, 1969, 1975) or lower (Kinoshita et al., 1976) than that of other human prematures. Our experiment shows that body weight gain and organ weight gain in premature mice as in fullterm newborn mice are in inverse ratio to the number of newborns per litter throughout the several stages of postnatal development studied. Thus, weight differences are equal in premature mice and full-term newborns, and the rapid recovery from the weight handicap in premature mice is similar, whatever the 
number of newborns per litter. A study of the literature on the growth of premature infants does not indicate whether the smallest premature babies overcome their weight handicap or not (N'Koumoun, 1978); from various results, it seems that many prematures remain deficient in body weight for several years (Drillien, 1958a, 1958b ; Knobloch et al., 1959 ; Lubchenco et al., 1963 ; Robinson and Robinson, 1965 ; Rossier, 1969). This is not the case of premature mice which, very quickly after birth, overcome the body and organ weight handicaps they have at birth. Consequently, the mouse seems to be a good model for studying the growth of prematures, and the factors responsible for fast somatic development revealed by this study merit further investigation.

Reçu en janvier 1983. Accepté en mai 1983.

Acknowledgements. - This research program was supported by a grant from CNRS. The authors wish to thank P. Dichamp and Mrs. Tournaire for technical assistance.

Résumé. Développement somatique du prématuré de Souris entre la naissance et le sevrage.

Une étude statistique transversale de la croissance au cours du développement néonatal a été réalisée sur environ 2400 prématurés de Souris survivants. Les prématurés ont été obtenus par césarienne au $19^{\circ}$ jour de la gestation et réanimés pendant $30 \mathrm{~min}$; les prématurés survivants, de même que les nouveau-nés à terme délivrés spontanément par voie basse au $20^{\circ}$ jour de gestation (animaux de contrôle), ont été élevés à partir de la naissance par lés nourrices qui avaient mis bas au même moment. Seules ont été conservées pour l'étude statistique, les portées provenant de mères qui ont allaité régulièrement leurs nouveau-nés. Le développement somatique des prématurés a été estimé, comparativement à celui des nouveau-nés à terme, à partir de l'évolution du poids du corps et du poids de certains organes, comme le foie, le rein et la surrénale, après sacrifice des nouveau-nés à 5 périodes du développement : $30 \mathrm{~min}$ après la réanimation ou la parturition, $6 \mathrm{~h}$ après la naissance et à $9 \mathrm{~h}$ aux $2^{\mathrm{e}}, 6^{\mathrm{e}}$ et $20^{\circ}$ jours. La croissance a été analysée par les courbes de croissance, le gain de poids en \% et en mg par jour, les droites de régression et les coefficients d'allométrie. Les calculs des gains de poids ont été faits en fonction du nombre de nouveau-nés par portée. Le déficit pondéral du prématuré de Souris survivant touche à la naissance à la fois le corps, le rein et la surrénale. Après une précoce et transitoire perte de poids du corps et des organes qui apparaît au cours du 1er jour de vie, le déficit pondéral du prématuré est rattrapé avant le $20^{\circ}$ jour de la vie : entre la $6^{\circ}$ heure et le $2^{\mathrm{e}}$ jour pour le poids surrénalien, entre le $2^{\mathrm{e}}$ jour et le $6^{\mathrm{e}}$ jour pour le poids du foie et entre le $6^{\mathrm{e}}$ jour et le $20^{\mathrm{e}}$ jour pour le poids du rein et le poids du corps; au cours de ces périodes, le gain de poids pour le corps et les organes est plus élevé que chez les nouveau-nés à terme. Les gains de poids, aussi bien chez le prématuré que chez les nouveau-nés de contrôle, sont inversement proportionnels au nombre de nouveau-nés par portée. Le rôle de certains facteurs dans la croissance des organes du prématuré est envisagé et le développement somatique du prématuré de Souris survivant est comparé à celui du prématurissime humain.

\section{Références}

AUMAITRE B., DEGLAIRE B., LEBOST J., 1979. Prématurité de la mise-bas chez la truie et signification du poids à la naissance du porcelet. Ann. Biol. anim. Bioch. Biophys., 19, 267. 275.

BERTIN R., LOCTIN J., BEAUVALLET M., PORTET R., DELOST P., 1982. Le tissu adipeux brun du nouveau-né et du prématuré de Souris. J. Physiol., (in press). 
BOURLON J. P., 1973. Etude longitudinale de la croissance, du poids, de la taille et du périmètre crânien chez 119 prématurés de 25 à 31 semaines d'âge gestationnel, de la naissance à 18 mois. Th. Doct. Méd., Lyon, France, 79 pp.

CANTIER J., VÉZINHET A., ROUVIER R., DAUZIER L., 1969. Allométrie de croissance chez le Lapin (Oryctolagus cuniculus) Ann. Biol. anim. Bioch. Biophys., 9, 5-39.

CORNBLATH M., PARKER M. L., REISNER S. H., FORBES A. E., DAUGHADAY W. H., 1965. Secretion and métabolism of growth hormone in premature and full-term infants. $J$. clin. Endocr. Metab., 25, 209-218.

DRILLIEN C. M., 1958a. Growth and development in a group of children of very low birth weight. Arch. Dis. Child., 33, 10-19.

DRILLIEN C. M., 1958b. A longitudinal study of the growth and development of prematurely and maturely born children. Arch. Dis. Child., 33, 417-431.

GAIRDNER D., PEARSON J., 1971. A growth chart for premature and other infants. Arch. Dis. Child., 46, 783-787.

HATT J. J., FLUSIN M. F., CHAVANNE J., 1972. L'élevage et l'avenir des prématurés de poids égal ou inférieur à $1250 \mathrm{~g}$. Ann. Pédiat., 19, 67-71.

KINOSHITA K., NAKAGAWA T., IBARAGI K., 1976. Statistical analysis of birth-weight and postnatal growth. Acat obst. gynaec. jap., 23, 89-95.

KNOBLOCH M., PASAMICK B., HARPER P., RIDER R., 1959. The effect of prematurity on health and growth. Amer. J. Publ. HIth., 49, 1164-1173.

LOCTIN J., 1980. Obtention, mortalité, croissance et fonction mineralocorticö̈de du prématuré expérimental de Souris. Thèse $3^{\circ}$ Cycle, Clermont-Ferrand, France, 246 pp.

LOCTIN J., DELOST P., 1982. Plasma and adrenal aldosterone levels in premature mice at birth and during neonatal development. Steroids, 40, 319-329.

LOCTIN J., DELOST P., 1983a. Mortality in premature mice at birth and during neonatal development. Reprod. Nutr. Dévelop., 23, 293-301.

LOCTIN J., DELOST P., 1983b. Plasma and adrenal corticosterone concentrations and liver glycogen content in premature mice at birth and during neonatal development. Steroids (in press).

LUBCHENCO L. O., HORNER F. A., REE L. H., HIX I. E., METCALF D., COHIG R., ELLIOTT H. C., BOURG M., 1963. Sequelal of premature birth. Evaluation of premature infants of low birth weights at ten years of age. Amer. J. Dis. Child., 106, 101-105.

N'KOUMOUN S., 1978. Le nouveau-né de faible poids de naissance $11500-2000 \mathrm{~g})$. Devenir immédiat et à moyen terme. Th. Doct. Méd., Bordeaux, France, $125 \mathrm{pp}$.

ROBINSON N., ROBINSON H., 1965. A follow up study of children of low birth weight and control children at school age. Pediatrics, 35, 425-433.

ROSSIER A., 1969. Prématurité. Encyclopédie Médicochirurgicale, Paris, Pédiatrie १re enfance, 4002, S10, 1-16.

ROSSIER A., 1975. Les besoins nutritifs du nouveau-né et du prématuré. Med. Infant., 82, 677-701. 